DOI https://doi.org/10.30525/978-9934-588-80-8-1.59

\title{
ТЕОРІЯ ЕМОЦІЙНОГО ЛІДЕРСТВА У ВИКЛАДАННІ ДИСЦИПЛІНИ «ПЕДАГОГІКА ВИЩОЇ ШКОЛИ»
}

\author{
Нестуля C. I. \\ доктор педагогічних наук, дочент, \\ директор \\ Навчально-науковий інститут лідерства \\ Кононец Н. В. \\ доктор педагогічних наук, \\ доцент кафедри педагогіки та суспільних наук \\ ВНЗ Укоопспілки «Полтавський університет економіки і торгівлі» \\ м. Полтава, Украӥна
}

Метою роботи є висвітлення можливостей імплементації теорії емоційного лідерства у викладанні дисципліни «Педагогіка вищої школи», яка передбачає формування загальної та педагогічної культури викладача закладу вищої освіти (ЗВО) будь-якого профілю, озброєння магістрантів системою знань про процеси розвитку теорії та практики виховання i навчання студентів, сприяє становленню світогляду, педагогічного професіоналізму.

Послуговуючись акмеологічним підходом до визначення поняття педагогічного професіоналізму (І. Богданов, А. Деркач, О. Дубасенюк, О. Зазикін, Н. Кузьміна, В. Сластьонін та ін.), яке тлумачиться як інтегрована якість, що складається 3 діяльнісного й особистісного аспектів, яка детермінує високу професійно-педагогічну кваліфікацію та компетентність, наявність різноманітних навичок і вмінь, володіння сучасними алгоритмами та способами вирішення професійних завдань, що дозволяє здійснювати педагогічну діяльність 3 високою та стабільною продуктивністю й забезпечує ефективне вирішення професійних педагогічних завдань щодо навчання й виховання, слід наголосити, що воно $є$ складним, багатокомпонентним утворенням, одним із особистісних складників якого $є$ лідерський компонент лідерські якості та навички. Відтак, ми переконані, що педагогічний професіоналізм викладача сучасного ЗВО - це, насамперед, здатність бути лідером у професійній діяльності: у студентському та науковопедагогічному колективі. Продовжуючи цю тезу, вважаємо, що у процесі викладання дисципліни «Педагогіка вищої школи» варто 
звертатися й реалізовувати низку лідерських концепцій, однією $з$ яких $\epsilon$ теорія емоиійного лідерства. Її основні положення слугують визначають вектори внесення змін у викладанні цієї дисципліни у контексті необхідності донесення до магістрантів головної тези: педагогічна діяльність - це, насамперед, діяльність педагога-лідера; викладач ЗВО буде успішним, а його діяльність - результативною, якщо він прагнутиме до лідерства, вчитиметься лідерству, вчитиме лідерству своїх студентів.

Глибокий аналіз праць авторів зазначеної теорії (Д. Гоулман, Р. Бояціс, Е. Маккі, Д. Макклелланд та ін.) слугував підставою до низки висновків.

У сучасному освітньому просторі викладачі-лідери жорстко інтегровані в систему організаційно-управлінських відносин. Перед ними стоять цілком конкретні завдання забезпечення ефективності педагогічної діяльності у тих групах студентів, де вони викладають. При чому ефективність вимірюється цілком конкретними показниками, які очевидні для всіх: програмні результати навчання, сформованість компетентностей, окреслених в освітніх програмах, абсолютний та якісний показники навчання тощо. Зрештою, кожен викладач-лідер має виконувати як освітні й управлінські, так і власне лідерські функції, пов'язані 3 перспективним і поточним плануванням, організацією навчання, мотивацією навчальної й самостійної пізнавальної діяльності студентів і контролем за нею і т. ін.

Ефективний викладач-лідер завжди досягає успіху у вирішенні проблем і завдань, які стоять перед ним, його студентами, магістрантами, аспірантами й колегами (послідовниками), уміло організовуючи, мотивуючи й надихаючи їх на досягнення спільних цілей i застосовуючи відповідні до ситуації владні повноваження, методи впливу, стилі управління. На наше глибоке переконання, усі ці аспекти діяльності викладача-лідера $є$ реальністю, абстрагуватися від якої не може жоден викладач, якщо він справді хоче бути ефективним.

Імплементуючи теорію емоційного лідерства в освітній процес, варто головний акцент зробити на стосунках викладача зі студентами (принцип паритетності), й технологіях використання можливостей емоційного інтелекту 3 метою побудови освітньо-управлінських відносин лідерського типу. Відтак, викладач-лідер повинен прагнути до того, аби його студенти (магістранти, аспіранти, навіть колеги) стали його справжніми однодумцями й послідовниками, йшли за ним на основі внутрішньої мотивації на досягнення спільної мети, яка розцінювалась би ними як емоційно приваблива та значима. 
На наш погляд, домінантною $є$ теза (Д. Гоулман, Р. Бояціс, Х. Вайсбах, У. Дакс), згідно якої ми маємо готувати магістрів освітньої програми «Педагогіка вищої школи» - основне завдання педагогівлідерів, полягає в тому, щоб «запалювати» студентів, викликати в них готовність до дій.

Інша теза, якою слід керуватися в освітньому процесі - лідерство завжди має емоційну першооснову [2, с. 7]. Безумовно, педагогічний професіоналізм успішного викладача $3 \mathrm{BO}$ полягає в тому, що викладачлідер «має спрямовувати колективні емоції в потрібне русло, створювати атмосферу дружелюбності й уміло боротися 3 негативними настроями» в силу того, що «люди тягнуться до лідера, чекають від нього емоційної підтримки, шукають у нього співчуття» [4]. Так чи інакше, але лідерство як таке містить цей аспект і в контексті особистості педагога-лідера, професіонала своєї справи. Як переконливо доводять Д. Гоулман, Р. Бояціс, Е. Маккі, коли лідери пробуджують у людях позитивні емоції, вони розкривають у них найкращі сторони». Цей ефект автори теорії емоційного лідерства називають резонансом [3, с. 20-21].

Ми переконані, що при викладанні дисципліни «Педагогіка вищої школи» викладачам, які готують магістрів, майбутніх викладачів 3ВО слід пам'ятати, що основними завданнями педагогів-лідерів $\epsilon$ досягнення резонансу зі своїми студентами. При цьому педагог-лідер повинен опиратися не лише на власні здібності, але й враховувати емоційні характеристики своїх студентів.

«...Ефективний лідер, як зазначає Д. Гоулман, це не одинока зірка, яка випромінює чарівне світло й по-царськи дарує його людям. Істинні лідери віддають собі звіт у тому, що вони самі також є об'єктами управління: лідерство - процес двосторонньо спрямований. Будь-який лідер повинен уважно прислухатися до оточуючих і налаштовуватися на їх хвилю, щоб вловлювати сигнали, які допоможуть йому забезпечити гармонію в колективі. Справжні лідери розуміють, що всі ми - в одному човні» $[1$, с. 8$]$.

Саме завдяки вмінню розуміти себе й оточуючих, викладачі, які дотримуються стратегії резонансного лідерства, можуть стати кращими із кращих. Такі педагоги-лідери здатні надихнути студентський чи викладацький колектив на втілення в життя мрії, яка всього декілька років тому здавалась нездійсненою. I ця мрія на очах в усіх стає реальністю [4].

Безумовно, видатні педагоги-лідери спостережливі й уважні, завжди чуйно прислухаються до себе й оточуючого світу та розуміють (намагаються зрозуміти) почуття інших людей. Вони ніколи не 
відступають від принципів, не зраджують своїм цінностям і живуть повноцінним, емоційно насиченим життям. Такі педагоги-лідери володіють розвинутим емоційним інтелектом і наділені активною свідомістю; вони постійно займаються самоосвітою, самовдосконаленням, самоаналізом і прагнуть жити із глибоким розумінням своїх студентів, усіх людей, природи й суспільства. Лідери-викладачі, не дивлячись на невизначеність, яка панує у світі та освітньому просторі, ніколи не втрачають оптимізму й надихають оточуючих своєю вірою в те, що спільними зусиллями мрію можна зробити реальністю. При цьому справжні педагоги-лідери не лише витрачають масу енергії, переборюючи труднощі й витримуючи суворі випробування, але й прагнуть використовувати всі сприятливі можливості. До того ж у будь-якій, навіть найскладнішій ситуації, вони виявляють до свого оточення співчуття й емпатію.

Установлюючи позитивні емоційні стандарти, резонансний викладач-лідер надихає своїх студентів наслідувати їх, рівнятися на них. Як зазначають учені [1, с. 15], не випадково однією з ознак резонансного лідерства $є$ наявність прихильників, які тягнуться за лідером, розділяючи його запал та енергію. Варто зазначити, що 3 точки зору емоційного лідерства, резонанс посилює і продовжує емоційний вплив лідера. Чим сильніше співпадають емоційні «вібрації» викладача й студентів, тим менше непорозуміння в їх спілкуванні. Відтак, він стає своєрідним емоційним магнітом, до якого тягнуться інші [4]. Коли ж у викладача й студентів хороший настрій, вони краще працюють, оточуючі й події сприймаються більш позитивно. А це допомагає викладачам і студентам повірити у свої сили, стимулює творчість, увагу до почуттів і проблем інших, сприяє прийняттю ефективних рішень. Хороший настрій особливо важливий, коли мова йде про командну роботу. Здатність викладача-лідера вселити у студентів ентузіазм, створити настрій єднання може визначити професійний успіх команди і сприятиме результативності навчання.

Узагальнивши досліджень авторів теорії емоційного лідерства й практику освітньої діяльності доходимо висновку про те, що емоційний стан викладача-лідера та його дії реально впливають на психологічне самопочуття студентів, а значить і на якість їх навчальної діяльності. Наскільки ефективно викладач-лідер управляє почуттями студентів i використовує їх для досягнення групових цілей, залежить від рівня його емоційного інтелекту, а вже уміння викликати резонанс - ознака педагогів-лідерів із високим емоційним інтелектом. 


\title{
Література:
}

1. Бояцис Р., Макки Э. Резонансное лидерство: самосовершенствование и построение плодотворных взаимоотношений с людьми на основе активного сознания, оптимизма и эмпатии : пер. с англ. Москва : Альпина Бизнес Букс, 2007. 300 с.

2. Вайсбах Х., Дакс У. Эмоциональный интеллект. Москва : ЛикПресс, 1998. 247 с.

3. Гоулман Д., Бояцис Р., Макки Э. Эмоциональное лидерство: искусство управления людьми на основе эмоционального интеллекта : пер. с англ.; 3-е изд. Москва : Альпина Бизнес Букс, 2008. 301 с.

4. Нестуля С. І., Нестуля О. О. Основи лідерства. Наукові концепції (середина XX - початок XXI ст.) : навч. посіб. Полтава : ПУЕТ, 2016. $375 \mathrm{c}$.

DOI https://doi.org/10.30525/978-9934-588-80-8-1.60

\section{FORMATION OF PROFESSIONAL SKILLS OF THE FUTURE TEACHER IN HIGHER EDUCATION INSTITUTIONS DURING THE STUDY OF THE DISCIPLINE «PEDAGOGY OF ART»}

\author{
Nozdrova O. P. \\ Candidate of Pedagogical Sciences, \\ Senior Lecturer at the Department of Pedagogy \\ South Ukrainian National Pedagogical University \\ named after K. D. Ushynsky \\ Bartienieva I. O. \\ Candidate of Pedagogical Sciences, \\ Senior Lecturer at the Department of Pedagogy \\ South Ukrainian National Pedagogical University \\ named after K. D. Ushynsky \\ Odessa, Ukraine
}

The current state of socio-political, economic instability in society creates problems of socio-economic, psychological and pedagogical, professional nature in the field of art education. This situation creates psychological and economic barriers that limit the methodological provison of the artistic process, as well as reduce the level of qualification competence of the future teacher, namely the use of innovative technologies and 